\title{
PERBANDINGAN KEMAMPUAN PEMECAHAN MASALAH MATEMATIS SISWA ANTARA YANG BELAJAR MENGGUNAKAN PEMBELAJARAN PROBLEM BASED LEARNING DAN PROBLEM POSING
}

\author{
SEPTIAN WULANDARI \\ Email: septian.pmb09@ rocketmail.com \\ Jurusan Teknik Informatika, Universitas Indraprasta PGRI
}

\begin{abstract}
Abstrak. Kemampuan pemecahan masalah matematis siswa perlu didukung dengan peran guru dalam proses pembelajaran siswa. Namun, pembelajaran yang terjadi di sekolah pada umumnya dilaksanakan secara teacher oriented. Oleh karena itu, perlu adanya pembelajaran yang mampu memfasilitasi siswa sehingga siswa menjadi aktif dalam proses pembelajaran. Pembelajaran problem posing dan problem based learning dapat menjadi pilihan pembelajaran student centered. Berdasarkan pemaparan diatas, maka penelitian ini dilakukan untuk mengetahui perbedaan kemampuan pemecahan masalah antara siswa yang belajar menggunakan problem posing dengan siswa yang belajar menggunakan problem based learning. Teknik pengambilan sampel menggunakan two stage sampling, yaitu teknik purposive sample dan cluster random sampling, setelah diuji homogenitas dan normalitas. Kemudian, dilakukan uji kesamaan rata-rata antar kelas. Pengukuran validitas menggunakan validitas isi, konstruk, dan empiris. Koefisien reliabilitas instrumen dihitung menggunakan rumus Alpha Cronbach. Pengujian normalitas dengan uji Liliefors pada taraf signifikansi $\alpha=0,05$. Pengujian homogenitas dengan uji Fisherdan pengujian hipotesis dilakukan menggunakan uji- $t$ dengan taraf signifikansi $\alpha=0,05$. Hasil pengujian diperoleh nilai $t_{\text {hitung }}=3,759$ dan nilai $t_{0,95}=1,664$ sehingga $t_{\text {hitung }}>t_{0,95}$ maka tolak $H_{0}$ sehingga dapat disimpulkan bahwa kemampuan pemecahan masalah matematis siswa yang belajar dengan pembelajaran problem based learning lebih tinggi daripada problem posing.
\end{abstract}

Kata Kunci: Problem Posing, Problem Based Learning, Pemecahan Matematis Siswa.

\begin{abstract}
Mathematical problem solving ability of students need to be supported by the role of the teacher in the learning process of students. However, the learning that takes place in schools generally conducted teacher-oriented. Therefore, the need for learning that is able to facilitate students so that students become active in the learning process. Based on the above presentation, this research was conducted to determine the difference between the problem solving ability of students to learn to use problem posing with students who learn to use problem-based learning. The sampling technique using a twostage sampling, the technique purposive sampling and cluster random sampling, as tested homogeneity and normality, then, do equality test on average between classes. The sample measurements validity of using content validity, construct, and empirical. Instrument reliability coefficient is calculated using Cronbach Alpha. Testing normality test at significance level Liliefors $\alpha=0,05$. Testing homogeneity with Fisher's test and hypothesis testing was performed using t-test with a significance level $\alpha=0,05$. The result of validity are $t_{\text {hitung }}=3,759$ and $t_{0,95}=1,664, t_{\text {hitung }}>t_{0,95}$, then reject $\mathrm{H}_{0}$. It can be concluded that the mathematical problem solving ability of students to learn by learning problem based learning is higher than the problem posing.
\end{abstract}

Key Words: Problem Posing, Problem Based Learning, Mathematical Problem Solving 


\section{PENDAHULUAN}

Pemecahan masalah matematis merupakan salah satu kemampuan matematika yang penting dan perlu diperoleh oleh siswa dalam pembelajaran matematika.Hal ini sejalan dengan Hudojo yang menegaskan bahwa matematika yang disajikan kepada siswa-siswa yang berupa masalah akan memberikan motivasi kepada mereka untuk mempelajari pelajaran tersebut. Para siswa akan merasa puas bila mereka dapat memecahkan masalah yang dihadapkan kepadanya (Hudojo, 2001: 167). Kemampuan pemecahan masalah matematis siswa perlu didukung dengan peran guru dalam proses pembelajaran siswa. Namun, pada umumnya pembelajaran masih dilaksanakan secara konvensional (teacher oriented), di mana pembelajaran berpusat pada guru dengan penekanan penyebaran materi, sehingga siswa menjadi kurang aktif. Sedangkan, untuk membangun pola pikir siswa dalam pemecahan masalah matematis siswa perlu memproses pengetahuan serta berperan aktif mencari dan menemukan sendiri pengetahuannya. Pembelajaran yang menuntut siswa untuk berperan secara aktif dalam membangun pengetahuannya sendiri dinamakan pembelajaran student centered. Pembelajaran problem posing dan problem based learning dapat menjadi pilihan pembelajaran student centered. Poblem posing merupakan suatu pembelajaran yang mengharuskan siswa untuk menyusun pertanyaan sendiri atau memecahkan suatu soal menjadi pertanyaan-pertanyaan yang lebih sederhana dan mengacu pada penyelesaian soal tersebut, sedangkan, problem based learning adalah pembelajaran yang menggunakan masalah dunia nyata sebagai suatu konteks dalam pembelajaran untuk belajar tentang cara berpikir kritis, merangsang keterampilan siswa dalam memecahkan suatu masalah, dan untuk memperoleh konsep serta pengetahuandari suatu materi pelajaran.

Materi bangun ruang yang dianggap sulit oleh siswa adalah prisma tegak dan limas. Dalam pengajuan masalah atau pemberian situasi saat pembelajaran, prisma tegak dan limas juga dapat disajikan dengan menggunakan gambar atau soal cerita sehingga siswa mudah untuk mencari sumber yang relevan, membentuk ulang masalah menjadi lebih sederhana yang sesuai dengan pemehaman siswa, menganalisis masalah, mengolah masalah, serta dapat mencari solusi pemecahannya secara mandiri ataupun kelompok.

Berdasarkan pemaparan diatas, maka penelitian ini dilakukan untuk mengetahui perbedaan kemampuan pemecahan masalah antara siswa yang belajar menggunakan problem posing dengan siswa yang belajar menggunakan problem based learning dalam bangun ruang prisma tegak dan limas. Tujuan penelitian ini adalah untuk mengetahui apakah pembelajaran problem based learning dan problem posing dapat menjadi alternatif untuk mengukur kemampuan pemecahan masalah matematis siswa. Secara khusus bertujuan untuk mengetahui informasi perbedaan kemampuan pemecahan masalah matematis yang belajar menggunakan pembelajaran problem based learning dan yang belajar menggunakan pembelajaran problem posing.

\section{TINJAUAN PUSTAKA}

\section{Kemampuan Pemecahan Masalah}

Menurut Polya dalam Hudojo, terdapat dua macam masalah dalam matematika yaitu masalah untuk menemukan dan masalah untuk membuktikan (Hudojo, 2001:164). Masalah untuk menemukan merupakan suatu masalah dalam matematika yang berlandaskan pada data, syarat, dan objek yang digunakan dalam menyelesaikan suatu masalah, sedangkan masalah untuk membuktikan merupakan suatu masalah dalam matematika yang dalam penyelesaiannya menggunakan hipotesis dan kesimpulan dari suatu teorema untuk membuktikan kebenarannya. Wena yang mengatakan bahwa pemecahan masalah tidak sekedar sebagai bentuk kemampuan menerapkan aturan-aturan 
yang telah dikuasai melalui kegiatan-kegiatan belajar terdahulu, melainkan lebih dari itu, merupakan proses untuk mendapatkan seperangkat aturan pada tingkat yang lebih tinggi (Wena, 2009:52). Oleh karena itu, pemecahan masalah adalah suatu tantangan untuk menyelesaikan masalah tidak rutin yang memerlukan proses berpikir tingkat tinggi dengan menerapkan aturan-aturan yang telah dipelajari dan dikuasai serta membutuhkan hipotesis dan kesimpulan untuk menyelesaikannya.

Menurut Cooney dalam Hudojo, mengajar siswa untuk menyelesaikan masalahmasalah memungkinkan siswa itu menjadi lebih analitik di dalam mengambil keputusan di dalam kehidupan (Hudojo, 2001:167). Ini berarti kemampuan pemecahan masalah matematis perlu dimiliki oleh siswa untuk dapat menghubungkan semua pengetahuan matematika yang dimilikinya yaitu konsep, penalaran, menggunaan berbagai strategi, melakukan pemodelan yang relevan, dan melakukan konklusi dari solusi-solusi yang telah ditemukan untuk dapat digunakan dalam memecahkan masalah di kehidupan seharihari. Menurut Polya yang dikutip oleh Ramdhani, dalam memecahkan masalah terdapat empat langkah utama yaitu memahami masalahnya, menyusun rencana memecahkan masalah, melaksanakan rencana, dan menguji kembali atau verifikasi (Ramdhani, 2012:27-28).Dengan penerapan langkah-langkah pemecahan masalah Polya, maka diharapkan pembelajaran akan menjadi efektif serta dapat melatih kemampuan pemecahan masalah matematis siswa. Langkah-langkah ini juga dapat melatih kemampuan berpikir siswa agar lebih sistematis dalam menyelesaikan soal.Cara mengukur kemampuan pemecahan matematis siswa dapat dilakukan dengan soal uraian untuk diselesaikan secara tuntas dan penilaian akan dilakukan secara komperhensif. Dalam menilai indikator pemecahan masalah matematis yang akan digunakan adalah indikator dari penjelasan Polya.

\section{Pembelajaran Problem Posing}

Menurut Amin dalam Ramdhani, problem posing mulai dikembangkan pada tahun 1997 oleh Lynn D. English dan awal mulanya diterapkan dalam mata pelajaran matematika (Ramdhani, 2012:15). Brown dan Waltermenyatakan bahwa, one way of gaining an appreciation for the importance of problem posing is to related it to problem solving (Brown \& Walter, 2005:2). Pernyataan tersebut jelas menunjukkan bahwa problem posing mempunyai keterkaitan dengan pemecahan masalah. Menurut Silver dalam Irwan, problem posing memiliki tiga pengertian, yaitu:

a. Problem posing adalah perumusan soal sederhana atau perumusan ulang soal yang ada dengan beberapa perubahan agar lebih sederhana dan dapat dipahami dalam rangka memecahkan soal yang rumit (problem posing sebagai suatu langkah problem solving)

b. Problem posing adalah perumusan soal yang berkaitan dengan syarat-syarat pada soal yang telah dipecahkan dalam rangka mencari alternaif pemecahan lain atau mengkaji kembali langkah problem solving yang telah dilakukan

c. Problem posing adalah merumuskan atau membuat soal dari situasi yang diberikan (Irwan, 2011:3).

Dari beberapa pernyataan tersebut, dapat disimpulkan problem posing merupakan suatu pembelajaran yang dapat membuat siswa berpikir secara kreatif dalam mengembangkan kemampuan berpikir matematis serta mampu memecahkan masalah yang dihadapkan karena soal dan penyelesaiannya dirancang sendiri oleh siswa.

Problem posing penting dalam kurikulum matematika karena didalamnya terdapat aktivitas matematika yaitu siswa membangun masalah sendiri, setelah membangun masalah sendiri dan menyelesaikannya, siswa diminya untuk melihat kembali hasil pekerjaannya. Menurut Cai dan Brook dalam Irwan melihat kembali bukan untuk mencari 
ada yang salah atau tidak melainkan tujuannya adalah a) Membangun, menganalisis, dan membandingkan dengan bentuk penyelesaian yang lainnya (penyelesaian alternatif), b) Membuat soal sejenis serta penyelesaiannya, dan c) Membuat generalisasi (Irwan, 2011:4).

Pembelajaran dengan menggunakan problem posing akan membuat pembelajaran yang awalnya menggunakan teacher oriented akan berubah menjadi student oriented. Dengan pembelajaran yang berpusat pada siswa membuat siswa menjadi aktif, siswa menjadi terampil dalam menyelesaikan masalah, mendidik siswa untuk berpikir kritis, dan siswa menjadi termotivasi untuk belajar matematika.

Berikut diagram proses pembelajaran problem posing menurut Silver dan Cai dalam Ramdhani(Ramdhani, 2012: 25):

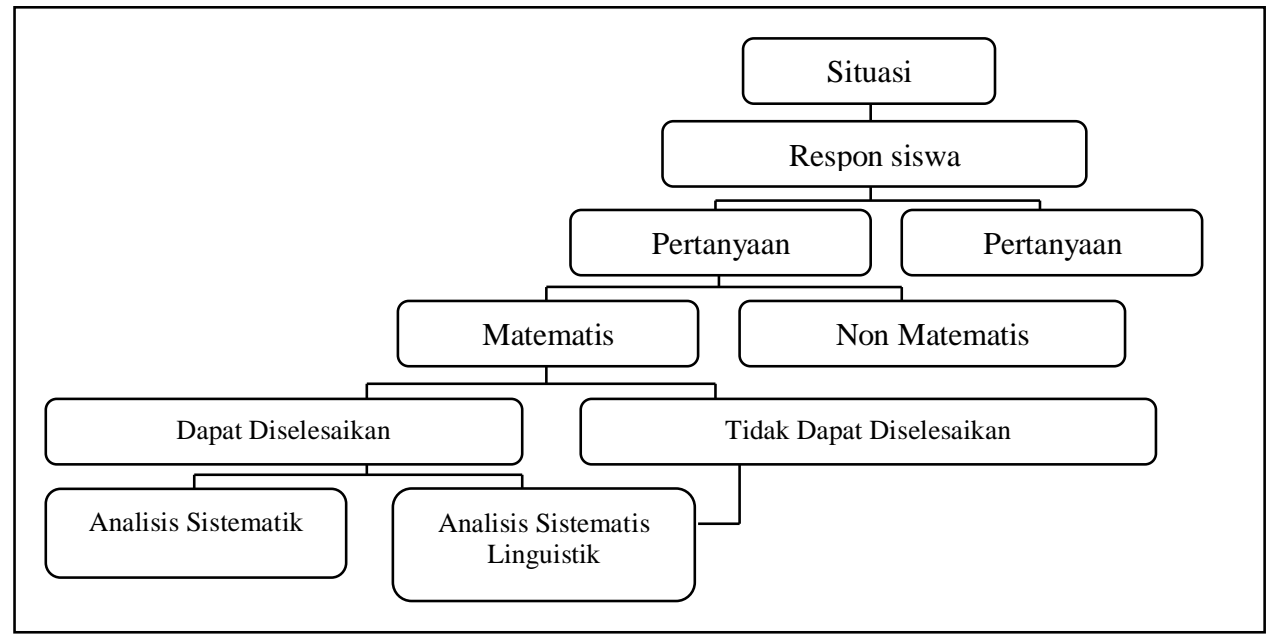

Gambar 1. Diagram Alur Pembelajaran Problem Posing

\section{Pembelajaran Problem Based Learning}

Siregar dan Nara menyatakan bahwa belajar berbasis masalah adalah salah satu bentuk pembelajaran yang berlandaskan pada teori belajar konstruktivisme, yang berorientasi pada proses belajar siswa (student-centered learning) (Siregar \& Nara, 2010: 108).Menurut Boud dan Felleti dan Fogarty dalam Hardini \& Puspitasari, belajar berbasis masalah merupakan suatu pembelajaran dengan membuat konfrontasi kepada siswa dengan masalah-masalah praktis, berbentuk ill-structured atau open-ended melalui stimulus dalam belajar (Hardini \& Puspitasari, 2012: 106). Dari beberapa definisi tersebut, terlihat bahwa problem based learning merupakan suatu pembelajaran yang berlandaskan masalah. Permasalahan yang dipelajari menjadi suatu stimulus dan pemandu dalam proses pembelajaran, kemudian siswa diminta untuk mencari pemecahannya melalui serangkaian penelitian dan investigasi berdasarkan teori, konsep, dan lain sebagainya sementara itu guru hanya menjadi fasilitator dan pembimbing.

Siregar dan Nara menyatakan PBL mempunyai banyak variasi diantaranya terdapat lima bentuk belajar berbasis masalah yaitu 1) permasalahan sebagai pemandu, 2) permasalahan sebagai kesatuan \& alat evaluasi, 3) permasalahan menjadi contoh, 4) permasalahan sebagai fasilitas proses belajar, dan 5) permasalahan sebagai stimulus belajar (Siregar \& Nara, 2010: 109). Ini berarti pembelajaran probem based learning memberikan kesempatan kepada siswa untuk bereksplorasi mengumpulkan, mengolah, dan menganalisis data yang ada untuk memecahkan masalah yang sedang dihadapi. Sehingga tujuan dari pembelajaran problem based learning adalah kemampuan siswa 
untuk dapat berpikir kritis, analistis, sistematis, dan logis untuk menemukan alternatif pemecahan masalah di dunia nyata melalui eksplorasi data secara empiris dalam rangka menumbuhkan sikap ilmiah.

Amir mengemukakan tujuh langkah proses problem based learning, umumnya setiap kelompok menjalankan proses yang sering disebut dengan proses 7 langkah yaitu: 1) Mengklarifikasi istilah dan konsep yang belum jelas, 2) Merumuskan masalah, 3) Menganalisis masalah, 4) Menata gagasan dan secara sistematis menganalisisnya dengan dalam, 5) Memformulasikan tujuan pembelajaran, 6) Mencari informasi tambahan dari sumber yang lain (di luar diskusi kelompok), 7) Mensintesa (menggabungkan) dan menguji informasi baru, dan membuat laporan untuk dosen/kelas) (Amir, 2009: 24).

Tujuh langkah PBL dalam 3 pertemuan menurut Amir adalah sebagai berikut:

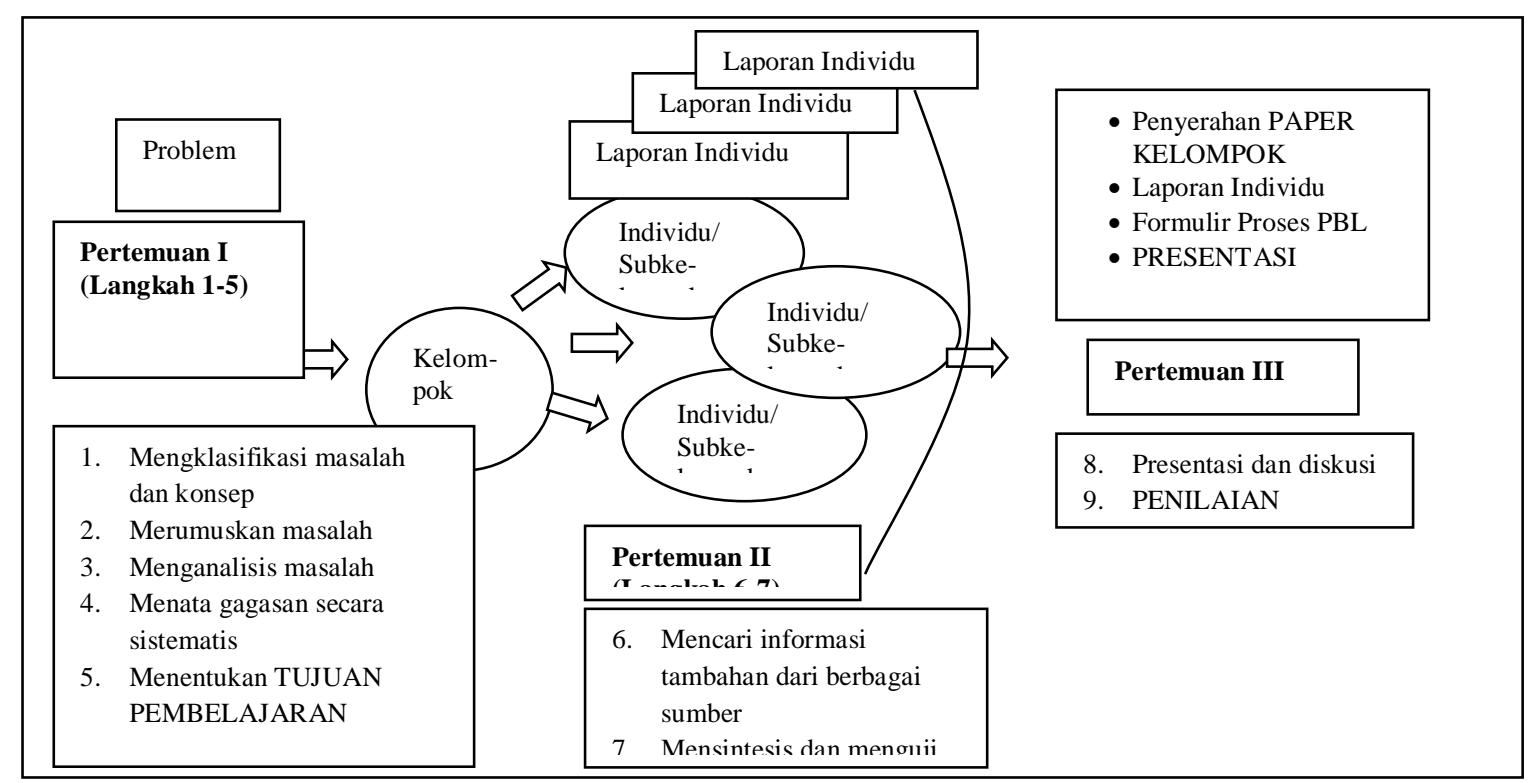

Gambar 2. Tujuan Langkah PBL dalam 3 Pertemuan [8]

\section{METODE}

Metode yang digunakan dalam penelitian ini adalah quasieksperiment.Dalam penelitian ini dilakukan perlakuan terhadap variabel bebas yaitu pembelajaran problem based learning dan pembelajaran problem posing, sedangkan variabel terikat adalah kemampuan pemecahan masalah matematis siswa. Penelitian ini dilakukan terhadap dua kelas eksperimen yang homogen. kelas pertama adalah kelas yang diberi perlakuan pembelajaran problem based learning dan kelas kedua adalah kelas yang diberi perlakuan pembelajaran problem posing. Dengan demikian desain eksperimen dalam penelitian ini adalah sebagai berikut:

Tabel 1. Tabel Desain Penelitian (Sugiyono, 2010: 114)

\begin{tabular}{ccc}
\hline Kelompok & Perlakuan & Post-test \\
$\mathrm{E}_{1}$ & $\mathrm{X}_{1}$ & $\mathrm{Y}_{1}$ \\
$\mathrm{E}_{2}$ & $\mathrm{X}_{2}$ & $\mathrm{Y}_{2}$ \\
\hline
\end{tabular}

Keterangan:

$\mathrm{E}_{1} \quad$ :Kelas Eksperimen I

$\mathrm{E}_{2} \quad$ :Kelas Eksperimen II 


\section{$\mathrm{X}_{1} \quad$ :Perlakuan pada Kelas Eksperimen I (pembelajaran problem based learning) \\ $\mathrm{X}_{2} \quad$ :Perlakuan pada Kelas Eksperimen II (pembelajaran problem posing) \\ $\mathrm{Y}_{1} \quad$ :Post-test pada kelas eksperimen I \\ $\mathrm{Y}_{2} \quad$ :Post-test pada kelas eksperimen II}

Teknik pengambilan sampel yang digunakan dalam penelitian ini adalah two stage sampling, yaitu pemilihan sampel dengan dua langkah. Pertama, menggunakan teknik purposive sample, dengan mempertimbangkan tersedianya guru yang mengajar di kelas yang berbeda-beda, tentu tidak mungkin memilih semua kelas yang diajarkan oleh guru yang berbeda-beda. Maka diambilah kelas yang diajarkan oleh guru yang sama. Kedua, menggunakan teknik cluster random sampling, memilih dua kelas yang mempunyai kondisi awal yang sama dan diajarkan oleh guru yang sama. Populasi target pada penelitian ini adalah seluruh seluruh siswa SMP Negeri 8 Depok tahun ajaran 2012/2013.Populasi terjangkau pada penelitian ini adalah seluruh siswa kelas VIII di SMP Negeri 8 Depok tahun ajaran 2012/2013 dengan jumlah 383 siswa.

Teknik pengambilan sampel dalam penelitian ini yaitu:

a. Mengambil sampel empat kelas yang diajar oleh guru yang sama (purposive sampel) pada kelas VIII di SMP Negeri 8 Depok.

b. Menguji homogenitas dan normalitas, empat kelas yang ada ditetapkan sebagai populasi homogen dan berdistribusi normal. Kemudian, dilakukan uji kesamaan ratarata antar kelas dengan uji anava satu arah yaitu kelas VIII-5, VIII-6, VIII-9, dan VIII10. Masing-masing kelas memiliki kesamaan rata-rata, maka dapat dilakukan pengambilan dua kelas secara acak (cluster random sampling)sebagai sampel penelitian terhadap keempat kelas ini.

c. Dua kelas tersebut yaitu kelas VIII-5 sebagai kelas eksperimen I dengan diberi perlakuan pembelajaran problem based learning dan kelas VIII-6 sebagai kelas eksperimen II dengan diberi perlakuan pembelajaran problem posing.

Sebelum penelitian ini dilakukan instrumen akan diujicobakan terlebih dahulu, agar mendapatkan alat evaluasi yang berkualitas baik. Alat evaluasi yang baik dilihat dari uji instrumen yaitu uji validitas dan realiabilitas.

Hasil pengujian validitas penelitian terhadap 25 siswa kelas IX di SMP 8 Depok adalah dari 5 soal instrumen terdapat 1 soal yang tidak valid, sehingga jumlah instrumen soal yang dinyatakan valid adalah 4 soal. Hasil pengujian reliabilitas terhadap 4 soal yang dinyatakan valid memiliki nilai $r_{11}=0,603$ maka kriteria yang diperoleh adalah cukup sehingga instrumen tes memenuhi kriteria valid maka instrumen itu juga reliabel. Analisis data dilakukan secara inferensial dengan independent sample t-test, setelah terlebih dahulu dilakukan pengujian normalitas dan homogenitas.

\section{HASIL DAN PEMBAHASAN}

\section{Pengujian Prasyarat Analisis Data}

\section{Uji Normalitas}

Untuk mengetahui data yang digunakan berasal dari populasi yang berdistribusi normal dilakukan pengujian dengan menggunakan uji Liliefors. Kriteria pengujian adalah tolak $\mathrm{H}_{0}$ jika $L_{\text {hitung }}>L_{\text {tabel }}$ pada taraf signifikansi $\alpha=0,05$. Data yang digunakan adalah data kemampuan pemecahan masalah matematis siswa setelah perlakuan pembelajaran untuk masing-masing kelas eksperimen.

Dari hasil pengujian pada kelas eksperimen I diperoleh $L_{\text {hitung }}=0,1027$ dan $L_{\text {tabel }}=0,1437$ (lampiran 29, halaman 181) untuk $\mathrm{n}=38$. Hasil pengujian pada kelas eksperimen II diperoleh $L_{\text {hitung }}=0,1189$ dan $L_{\text {tabel }}=0,1419$ untuk $\mathrm{n}=39$. 
Berdasarkan hasil pengujian didapat nilai $L_{0}$ pada kedua kelas eksperimen kurang dar $L_{\text {tabel }}$ maka terima $H_{0}$. Sehingga dapat disimpulkan bahwa data kemampuan pemecahan masalah matematis siswa dari kedua kelas eksperimen setelah diberikan perlakuan berasal dari populasi yang berdistribusi normal.

Tabel 2. Rekapitulasi Hasil Uji Normalitas

\begin{tabular}{|c|c|c|c|c|}
\hline $\begin{array}{c}\text { Kelas } \\
\text { Eksperimen }\end{array}$ & $\begin{array}{l}\text { Jumlah } \\
\text { Sampel }\end{array}$ & $\mathrm{L}_{\text {hitung }}$ & $\mathrm{L}_{\text {tabel }}$ & Kesimpulan \\
\hline $\begin{array}{l}\text { I (Problem Based } \\
\text { Learning) }\end{array}$ & 38 & 0,1027 & 0,1437 & $\begin{array}{l}\text { Berdistribusi } \\
\text { normal }\end{array}$ \\
\hline $\begin{array}{c}\text { II (Problem } \\
\text { Posing) }\end{array}$ & 39 & 0,1189 & 0,1419 & $\begin{array}{c}\text { Berdistribusi } \\
\text { normal }\end{array}$ \\
\hline
\end{tabular}

\section{Pengujian Homogenitas}

Uji homogenitas setelah diberikan perlakuan menggunakan uji Fisher pada taraf signifikansi $\alpha=0,05$ dengan kriteria pengujian adalah tolak $\mathrm{H}_{0}$ jika $F_{\text {hitung }}>F_{\text {tabel }}$. Dari hasil pengujian diperoleh $F_{\text {hitung }}=1.712436$ dan $F_{\text {tabel }}=1.7929$ sehingga $F_{\text {hitung }}<F_{\text {tabel }}$. Berdasarkan hasil diatas maka terima $\mathrm{H}_{0}$ atau dapat disimpulkan bahwa kelas eksperimen I dan kelas eksperimen II setelah diberikan perlakuan pembelajaran memiliki varians yang homogen.

\section{Pengujian Hipotesis}

Pengujian hipotesis dilakukan dengan menggunakan uji- $t$ kesamaan dua rata-rata satu pihak (uji pihak kanan) karena kelas eksperimen memiliki varians yang homogen dengan kondisi varians yang sama pada taraf signifikansi $\alpha=0,05$ dan derajat kebebasan $d k=$ $n_{1}+n_{2}-2$. Berdasarkan hasil pengujian diperoleh nilai $t_{\text {hitung }}=3,759$ dan nilai $t_{0,95}=1,664$ sehingga $t_{\text {hitung }}>t_{0,95}$. Berdasarkan hasil tersebut maka tolak $H_{0}$ atau dapat disimpulkan bahwa kemampuan pemecahan masalah matematis siswa yang belajar dengan pembelajaran problem based learning lebih tinggi daripada problem posing.

\section{Pembahasan}

Hasil pengujian hipotesis ini menunjukkan bahwa terdapat pengaruh bentuk pembelajaran terhadap kemampuan pemecahan masalah matematis siswa. Bentuk pembelajaran yang digunakan dalam penelitian ini adalah pembelajaran problem based learning dan problem posing.

Pembelajaran problem based learning dibantu dengan lembar aktivitas siswa sebagai langkah-langkah untuk mengarahkan siswa menuju pada pemecahan masalah sehingga siswa dapat menyelesaikan masalah yang sedang dihadapi. Langkah-langkah problem based learning mempunyai beberapa kesamaan dengan langkah-langkah dalam pemecahan masalah matematis seperti memahami masalah, mendiagnosis masalah, merumuskan alternatif strategi, menentukan dan menerapkan strategi pilihan, dan melakukan evaluasi. Hal ini membuat siswa menjadi terlatih dalam memecahkan masalah matematis yang memiliki langkah-langkah seperti memahami masalah, merencanaan penyelesaian masalah, melaksanakan rencana penyelesaian masalah, serta menguji kembali atau verifikasi. Berbeda dengan pembelajaran problem posing yang dibantu lembar aktivitas siswa berupa situasi-situasi tertentu sebagai media dalam membuat masalah tanpa adanya langkah-langkah siswa dalam memecahkan masalah yang dibuatnya. Hal ini membuat siswa-siswa yang belajar dengan pembelajaran problem based learning telah terlatih untuk memecahkan masalah matematis disbanding siswa yang belajar dengan pembelajaran problem posing. 


\section{PENUTUP}

Penelitian ini merupakan penelitian quasi eksperimen yang membandingkan pembelajaran problem based learning dan problem posing. Perbandingan kedua pembelajaran tersebut dilakukan dengan membandingkan nilai rata-rata tes kemampuan pemecahan masalah matematis siswa setelah diberi perlakuan yang berbeda. Data hasil penelitian diambil dari hasil tes kemampuan pemecahan masalah matematis siswa pada materi bangun ruang prisma dan limas tegak. Data yang telah diperoleh diuji dengan menggunakan uji- $t$ karena memiliki varian yang sama atau homogen. Kesimpulan dalam penelitian ini adalah kemampuan pemecahan masalah matematis siswa yang belajar dengan pembelajaran problem based learning lebih tinggi daripada pembelajaran problem posing pada materi bangun ruang prisma dan limas tegak di SMP Negeri 8 Depok.

\section{DAFTAR PUSTAKA}

Hudojo, H. 2001. Common Textbook: Pengembangan Kurikulum dan Pembelajaran Matematika. Malang: JICA.

Wena, M. 2009. Strategi Pembelajaran Inovasi Kontemporer: Suatu Tinjauan Konseptual Operasional. Jakarta: Bumi Aksara.

Ramdhani, S. 2012.Pembelajaran Matematika dengan Pendekatan Problem Posing untuk Meningkatkan Kemampuan Pemecahan Masalah dan Koneksi Matematis Siswa. Tesis. UPI. [Online] . Tersedia: http://repository.upi.edu/operator/upload/t_mtk_1006953_chapter2.pdf. [Diakses 18 Februari 2013].

Brown, S. I., \& Walter, M. I. The Art of Problem Posing (3rd edition). New Jersey: Lawrence Erlbaum Associates Publishers. 2005.

Irwan. 2011. Pengaruh Pendekatan Problem Posing Model Search, Solve, Create, and Share (SSCS) dalam Upaya Meningkatkan Kemampuan Penalaran Matematis Mahasiswa Matematika. Jurnal FMIPA UNP. [Online]. Tersedia: http://jurnal.upi.edu/file/irwan.pdf. [Diakses 15 Februari 2013].

Siregar, E., \& Nara, H. 2010. Buku Ajar Teori Belajar dan Pembelajaran. Jakarta: UNJ.

Hardini, I., \& Puspitasari, D. 2012. Strategi Pembelajaran Terpadu (Teori, Konsep, \& Implementasi). Yogyakarta: Familia.

Amir, M. T. 2009. Inovasi Pendidikan Melalui Problem Based Learning: Bagaimana Pendidik Memberdayakan Pemelajar di Era Pengetahuan. Jakarta: Media Group.

Sugiyono. 2010. Metode Penelitian Pendidikan Kuantitatif, Kualitatif, dan R\&D. Bandung: Alfabeta.

Sudjana, N. 2009. Penilaian Hasil Proses Belajar Mengajar. Bandung: Remaja Rosdakarya.

Riduan. 2004. Belajar Mudah Penelitian Untuk Guru - Karyawan dan Peneliti Muda. Bandung: Alfabeta.

Sugiyono. 2010. Metode Penelitian Pendidikan Kuantitatif, Kualitatif, dan R\&D. Bandung: Alfabeta. 